\title{
Peranan Kinerja Amil Mengelola Zakat Produktif dalam Mengentaskan Kemiskinan Di Kota Banda Aceh
}

\author{
Nurbismi \\ Prodi Manajemen, Sekolah Tinggi Ilmu Ekonomi Sabang Banda Aceh \\ e-mail: nurbismi_yazid@yahoo.com \\ Zenitha Maulida \\ Prodi Manajemen, Sekolah Tinggi Ilmu Ekonomi Sabang Banda Aceh \\ e-mail: zenitha.abadi@gmail.com \\ Ainul Ridha \\ Prodi Akuntansi, Sekolah Tinggi Ilmu Ekonomi Sabang Banda Aceh \\ e-mail:aynul.ridha@gmail.com \\ Intan Novia Astuti \\ Prodi Akuntansi, Sekolah Tinggi Ilmu Ekonomi Sabang Banda Aceh \\ e-mail: intann42@yahoo.com
}

\begin{abstract}
The distribution of productive zakat targeted to be one of the achievement targets in reducing poverty in urban areas. Therefore, the distribution of productive zakat needs to be explored in a specific study in efforts to reduce poverty in Banda Aceh City. This research used multiple regression by placing the performance of amil zakat as a moderating variable. Sampling was conducted by 100 respondent of mustahik zakat productive in Banda Aceh. Based on the result, it is found that the amount of productive zakat, income, asset and business distribution are significantly influenced to decrease poverty level in Banda Aceh City. Performance amil not able to moderator variable for the field of business in zakat distribution. However, the performance of amil significantly effects as a moderating variable for productive zakat, income, and business assets in reducing the poverty of mustahik in Banda Aceh City. The moderation effects generated by the performance of amil are the pure moderator, the quasi moderator, and the predictor moderator. The conclusion that the performance of amil is able to reduce poverty levels in Kota Banda Aceh as a moderating variable.
\end{abstract}

Keywords: Performance Amil, productive Zakat, Poverty.

\section{PENDAHULUAN}

Kemiskinan menurut World Bank ditentukan oleh keberhasilan pembangunan di tingkat daerah. Upaya pembangunan yang dapat dilakukan pemerintah daerah dalam menanggulangi kemiskinan adalah salah satunya dengan mendorong pembangunan ekonomi. Keberhasilan dari pembangunan

ekonomi dapat dilihat dari peningkatan capaian indikator ekonomi seperti laju pertumbuhan ekonomi, investasi, serta PDRB per kapita (Bappenas \& BPS, 2013).

Kota Banda Aceh sebagai daerah perkotaan di Provinsi Aceh tergolong sebagai daerah dengan kemajuan perekonomian yang 
pesat. Hal ini terlihat berdasarkan rata-rata pertumbuhan ekonomi Kota Banda Aceh selama lima tahun (2010-2015) yang mampu mencapai angka 5,42\% atau berada di atas rata-rata pertumbuhan ekonomi Provinsi Aceh yang hanya 2,78\% (BPS Provinsi Aceh, 2016). Pertumbuhan ekonomi yang tinggi di Kota Banda Aceh itu, namun demikian, ternyata dihadapkan pada permasalahan ketimpangan pendapatan yang tinggi.

Zakat merupakan salah satu sumber pendapatan daerah yang memegang peranan penting dalam perbaikan ekonomi masyakat. Utama zakat produktif bagi daerah perkotaan yang notabene didominasi oleh sektor usaha perdagangan. Zakat produktif dalam proses manajemen distribusinya dinilai masih belum memberikan titik target khusus dalam hal mereduksi kemiskinan. Baitul Mal Kota Banda Aceh berdasarkan data penerimaan zakat Kota Banda Aceh, pada tahun 2015 penerimaan zakat yang terhimpun sebesar Rp. 16,84 Milliar. Jumlah zakat yang besar ini dikonversi dengan garis kemiskinan maka terlihat adanya kesenjangan cukup tinggi.

Kemiskinan menyebabkan seseorang ataupun sekelompok orang tidak mampu memenuhi hak-hak dasarnya seperti tidak terpenuhinya kebutuhan pangan, kesehatan, pendidikan, pekerjaan, perumahan, air bersih, pertanahan, sumber daya alam serta lingkungan hidup. Perkembangan kota dipengaruhi proses terjadinya urbanisasi yang dapat dilihat berdasarkan demografi, ekonomi, dan sosial.

Berkaitan aspek demografi, pertumbuhan penduduk di perkotaan yang tinggi sebagai akibat dari magnet migrasi penduduk berefek pada meningkatnya persaingan yang membawa kepada siklus kemiskinan. Perkembangan itu juga disebabkan adanya perubahan ekonomi yang terlihat dari adanya pergeseran lapangan pekerjaan dari sektor pertanian ke sektor non pertanian, seperti perdagangan dan industri. Sedangkan berdasarkan aspek sosial, perkembangan wilayah perkotaan terlihat dari adanya perubahan pola pikir dan gaya hidup masyarakatnya (McGee, 1971). Selain itu, adanya permukiman kumuh dengan keterbatasan sarana dan prasarana pendukung menunjukkan adanya kantongkantong kemiskinan (slum area) di perkotaan.
Berbagai program terkait pengentasan kemiskinan sudah dijalankan, tetapi hasilnya belum seperti yang diharapkan. Di sisi lain, keberhasilan pembangunan nasional sangat ditentukan oleh keberhasilan pembangunan di tingkat daerah. Upaya pembangunan yang dapat dilakukan pemerintah daerah dalam rangka menanggulangi kemiskinan salah satunya dengan mendorong pembangunan ekonomi. Keberhasilan dari pembangunan ekonomi dapat dilihat dari peningkatan capaian indikator ekonomi seperti laju pertumbuhan ekonomi, investasi, serta PDRB per kapita (Bappenas \& BPS, 2013). Data zakat dan garis kemiskinan kota Banda Aceh dapat dilihat pada Gambar 1.

Berdasarkan tabulasi data penerimaan zakat yang dikomparasikan dengan pola pergerakan garis kemiskinan di dalam Gambar 1, terlihat adanya trend searah yang terjadi dimulai pada tahun 2012-2015. Hal ini mengindikasikan bahwa tingginya zakat yang dikumpulkan maka diikuti kenaikan garis kemiskinan. Hal ini yang menjadikan penelitian ini berupaya menjawab masalah kemiskinan area perkotaan dengan menjadikan kinerja amil dalam mengelola zakat produktif sebagai komponen utama dalam upaya mereduksi kemiskinan di Kota Banda Aceh.

Berdasarkan latar pemikiran yang telah diuraikan, maka rumusan masalah yang ingin dijawab penelitian ini adalah: (1) Apakah kinerja amil mampu mereduksi kemiskinan di Kota Banda Aceh?; serta, (2) Bagaimana efek yang ditimbulkan dari interaksi Kinerja Amil dengan penyaluran zakat, pendapatan mustahik, bidang usaha, dan asset usaha?

\section{Kemiskinan}

Kemiskinan di perkotaan dipicu oleh perkembangan kota yang semakin pesat, tercermin dari pesatnya perluasan wilayah kota, tingginya tingkat urbanisasi, meningkatnya perkembangan ekonomi yang ditandai adanya konsentrasi berbagai macam kegiatan ekonomi, terutama industri, jasa-jasa modern, dan perdagangan. Perubahan sosial dan modernisasi kehidupan telah mengubah kehidupan pola konsumsi, gaya hidup, dan perilaku sosial menuju pada perbaikan kesejahteraan (Shalimow, 2004). 


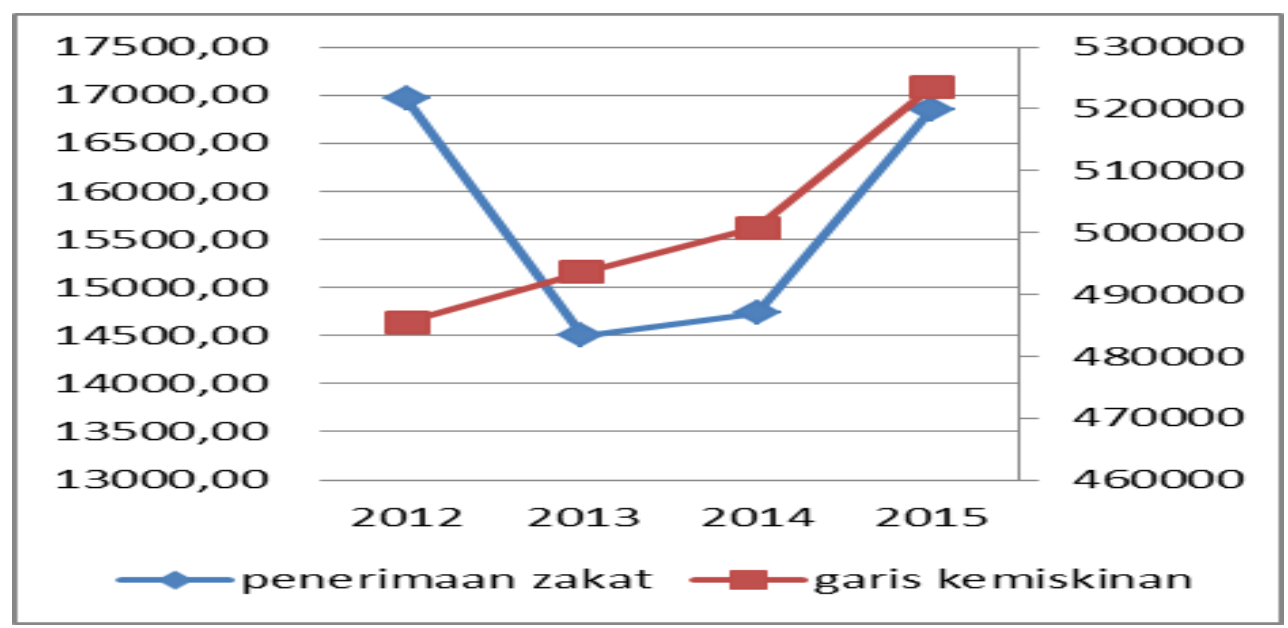

\section{Gambar 1. Grafik Penerimaan Zakat dan Garis Kemiskinan Kota Banda Aceh Tahun 2012-2015}

\section{Zakat}

Menurut Muhammad (2009), zakat merupakan harta yang diambil dari amanah harta yang dikelola oleh orang kaya, yang ditransfer kepada kelompok fakir dan miskin serta kelompok lain yang telah ditentukan dalam Al-Qur'an, yang lazim disebut kelompok mustahik. Dalam istilah ekonomi, zakat merupakan tindakan transfer of income (pemindahan kekayaan) dari golongan kaya (agniya/the have) kepada golongan yang tidak berpunya (the have not).

Qadir (2001) menyatakan bahwa zakat produktif yaitu zakat yang diberikan kepada mustahik sebagai modal untuk menjalankan suatu kegiatan ekonomi yaitu untuk menumbuhkembangkan tingkat ekonomi dan potensi produktivitas mustahik. Hal tersebut diperkuat oleh Muhammad (2009) yang bependapat bahwa zakat merupakan harta yang diambil dari amanah harta yang dikelola oleh orang kaya, yang ditransfer kepada kelompok fakir dan miskin serta kelompok lain yang telah ditentukan dalam al-Qur'an.

Jadi, dapat disimpulkan bahwa zakat produktif adalah harta yang diambil dari amanah harta yang dimiliki oleh muzakki dan diberikan kepada mustahik sebagai modal untuk menjalankan kegiatan perekonomian mustahik untuk mengembangkan tingkat keadaan ekonomi mustahik.

Penggunaan zakat secara produktif, lebih kepada bagaimana cara atau metode menyampaikan dana zakat kepada sasaran dalam pengertian yang lebih luas, sesuai dengan tujuan syara'. Cara pemberian yang tepat dan berguna, efektif manfaatnya dengan sistem yang ada dan produktif (Bandadeh, 2016). Istilah lainnya zakat produktif, dana yang diberikan kepada seseorang atau masyarakat untuk digunakan sebagai modal kerja yang diperoleh dari harta zakat (Huda, 2012).

Zakat produktif mendapat perhatian yang mendalam oleh Ridwan dalam bukunya "Baitul Maal bi Tamwil" (2005), yang menjelaskan urgensi pendayagunaan zakat harus berdampak positif bagi mustahiq, baik secara ekonomi maupun sosial.Hal ini berarti, zakat tidak hanya didistribusikan untuk halhal yang konsumtif saja dan hanya bersifat charity tetapi lebih untuk kepentingan yang produktif dan bersifat edukatif.Untuk itu, zakat usaha produktif pada tahap awal harus mampu mendidik mustahiq sehingga benarbenar siap untuk berubah. Karena tidak mungkin kemiskinan itu dapat berubah kecuali dimulai dari perubahan mental si miskin itu sendiri. Inilah yang disebut peran pemberdayaan. Zakat yang dapat dihimpun dalam jangka panjang seharusnya dapat memberdayakan mustahiq sampai kepada dataran pengembangan usaha.

\section{Manajemen Distribusi Zakat Produktif}

Pendistribusian dana zakat kini telah berkembang, dari awalnya hanya berorientasi 
pada pemenuhan kebutuhan konsumtif telah menjadi sumber dana produktif yang dapat mendongkrak perekonomian lebih jauh lagi. Di Indonesia sendiri, zakat produktif di ahkan MUI pada tahun 1982. Juga diperkuat dengan adanya keterangan mengenai zakat yang dikumpulkan Lembaga Amil Zakat (LAZ) maupun Badan Amil Zakat (BAZ) bisa diberikan secara konsumtif untuk keperluan memenuhi kebutuhan hidup sehari-hari dan bisa pula secara produktif meningkatkan usaha yang dilakukan oleh para mustahik (Hafidhuddin, 2002).

Dalam lembaga zakat, terdapat tiga komponen tata kelola, yakni penghimpunan, pengelolaan dan pendayagunaan. Ketiganya dimasukkan dalam tiga divisi utama, yaitu divisi penghimpunan, divisi pendistribusian dan pendayagunaan serta yang ketiga divisi sosialisasi dan pembinaan. Divisi yang sangat terkait dengan muzakki adalah divisi penghimpunan dana ziswaf.

Masing-masing divisi memiliki tugas pokok dan fungsi yang dijalankan untuk pengelolaan Baitul Mal yang baik dan benar. Divisi penghimpunan mempunyai tugas pokok dan fungsi; Pelaksanaan inventarisasi dan pendataan muzakki untuk menghitung potensi zakat secara keseluruhan, baik dari Unit Pengumpul Zakat, Perusahaan, dan Perorangan, Pelaksanaan penetapan jumlah zakat yang harus dibayar, Pelaksanaan penyusunan rencana operasional pengumpulan zakat, infaq, shadaqah, Penyelenggaraan administrasi pendataan zakat, wakaf dan harta agama dan pelaporannya sesuai dengan ketentuan akuntansi, Pelaksanaan penyusunan pelaporan secara periodik, Pelaksanaan koordinasi dengan lembaga dan atau instansi terkait lainnya di bidang pengumpulan zakat, wakaf dan harta agama lainnya dan Pelaksanaan tugas-tugas kedinasan lainnya yang diberikan Kepala Baitul Mal.

Divisi pendistribusian dan pendayagunaan memiliki tugas pokok dan fungsi; Pelaksanaan pendataan mustahiq sesuai dengan ketentuan syariat, Pelaksanaan penetapan potensi zakat dan penyaluran zakat baik zakat konsumtif maupun zakat produktif, Pelaksanaan penyaluran zakat produktif kepada unit pengelola zakat produktif,
Pelaksanaan penyusunan program operasional pembinaan pihak mustahik, Penyelenggaraan administrasi distribusi zakat dan pelaporan sesuai ketentuan akuntansi, Pelaksanaan koordinasi dengan lembaga dan atau instansi terkait lainnya di bidang pendistribusian dan pendayagunaan zakat, dan Pelaksanaan tugastugas kedinasan lainnya yang diberikan oleh Kepala Baitul Mal Kota.

Divisi yang terakhir adalah devisi sosialisasi dan pembinaan memiliki tugas pokok dan fungsi berupa Pelaksanaan penyusunan program sosialisasi dan pembinaan, pelaksanaan sosialisasi dan penyuluhan kepada masyarakat, pelaksanaan pembinaan dan pengawasan terhadap pengelolaan zakat, waqaf, harta agama, infaq, dan shadaqah, pelaksanaan pembinaan dan pengawasan terhadap kegiatan Baitul Mal kemukiman dan gampong, pelaksanaan hubungan kerjasama dengan ulama-umara dalam rangka memasyarakatkan kewajiban membayar zakat, pelaksanaan pemantauan, evaluasi, dan pelaporan, Pelaksanaan koordinasi dengan lembaga dan atau instansi terkait lainnya di bidang sosialisasi dan pembinaan pengelolaan zakat, wakaf, harta agama, infaq dan shadaqah, dan Pelaksanaan tugas-tugas kedinasan lainnya yang diberikan oleh Kepala Baitul Mal Kota (http:// baitulmal.bandaacehkota.go.id/).

Dalam arah pengembangannya, pola distribusi zakat mengalami perubahan paradigma dari zakat secara konsumtif menuju pada zakat produktif. Zakat produktif adalah zakat produktif yaitu zakat yang diberikan kepada mustahik sebagai modal untuk menjalankan suatu kegiatan ekonomi yaitu untuk menumbuhkembangkan tingkat ekonomi dan potensi produktivitas mustahik (Qadir, 2001), sedangkan zakat konsumtif merupakan zakat yang diberikan kepada 8 (delapan) asnaf untuk memenuhi kebutuhan sehari-hari. Akan tetapi zakat konsumtif ini kurang begitu membantu untuk kebutuhan jangka panjang. Hal ini dikarenakan zakat konsumtif hanya memenuhi kebutuhan seharihari dan akan habis tanpa menghasilkan atau hanya untuk jangka pendek. Maka dari itu, diperlukan juga pola pendidstribusian zakat 
yang bersifat zakat produktif kepada para mustahiq (https://diy.baznas.go.id).

Pemberian zakat secara produktif, sebagaimana pendapat yang dikemukakan oleh Qardawi (dalam Nawawi, 2010) diterangkan bahwa pemerintah Islam dapat mengembangkan harta zakat dengan cara membangun pabrik-pabrik atau perusahaanperusahaan, kemudian hasil keuntungannya dipergunakan untuk kepentingan fakir miskin sehingga akan terpenuhi kebutuhan hidup mereka sepanjang masa.

Pengganti pemerintah dapat diperankan oleh LAZ atau Badan Amil Zakat yang kuat amanah dan profesional. Lembaga atau Badan Amil Zakat bila memberikan zakat secara produktif harus melakukan pembinaan/ pendampingan kepada para mustahiq zakat agar kegiatan usahanya dapat berjalan baik.

Beberapa kajian yang membahas mengenai pemberdayaan sosial ekonomi mustahik zakat sebagaimana artikel yang ditulis oleh Iqbal (2012) tentang "Peranan dan kuasa Baitul Mal Aceh Dalam Pengurusan Zakat" yang menguraikan bahwa, Baitul Mal Aceh sangat berperan penting dalam meningkatkan perekonomian dari masyarakat, khususnya asnaf zakat. Baitul Mal Aceh perlu menciptakan berbagai macam terobosan baru dalam pengelolaan harta zakat, seperti meningkatkan pembiayaan produktif serta melakukan pendampingan terhadap penyaluran zakat produktif. Dengan adanya pendampingan tersebut, sehingga hakikat zakat dapat tercapai dengan baik.

Basyah (2009) menjelaskan tentang mekanisme administrasi dan pengelolaan zakat di Aceh. Pengelolaan zakat di Aceh memiliki kekhususan dalam berbagai daerah lain di Indonesia. Perbedaan utama adalah Baitul Mal sebagai lembaga resmi yang bertanggungjawab sebagai lembaga pengelolaan zakat di Aceh. Mekanisme pengelolaan zakat di Baitul Mal Aceh dalam memberantas kemiskinan melalui program pemberdayaan ekonomi masyarakat menghasilkan manfaat dalam jangka panjang dan melepaskan kebergantungan ekonomi dari pihak lain. Justru Baitul Mal Aceh telah berperan sangat penting dalam pembangunan ekonomi masyarakat miskin di Aceh.
Artikel yang dituliskan oleh Rusli et al. (2013) yang berjudul "Analisis Dampak Pemberian Modal Zakat Produktif Terhadap Pengentasan Kemiskinan Dikabupaten Aceh Utara" mengungkapkan bahwa pemberian modal zakat produktif dalam bentuk modal usaha berdampak positif dan dapat menurunkan angka kemiskinan di Kabupaten Aceh Utara sebesar 0,02\%. Oleh karena itu, pemberian zakat produktif dalam bentuk modal usaha oleh Baitul Mal Kabupaten Aceh Utara dapat lanjutkan dan ditingkatkan.

Johari et al. (2015) melakukan riset terhadap zakat yang diberikan kepada muallah dengan judul "The Role of Zakat in Reducing Poverty and Income Inequality among New Convert (Muallaf) in Selangor, Malaysia" menghasilkan suatu temuan bahwasannya distribusi zakat dapat mengurangi angka kemiskinan dan tingkat keparahan kemiskinan bagi muallaf. Model distribusi zakat dapat mengurangi kesenjangan pendapatan dan memaksimalkan kesejahteraan sosial. Dinilai perlu adanya kebijakan pemanfaatan sumber daya zakat secara efisien guna mencegah kelompok yang terkena dampak kesenjangan pendapatan.

\section{Kerangka Penelitian dan Hipotesis}

Kerangka model penelitian yang memperlihatkan keberadaan amil sebagai variabel pemoderasi antara di antara variabel itu seperti ditunjukkan dalam Gambar 2.

Sesuai kaedah MRA yang kemudian disesuaikan pada jumlah variabel independen dalam penelitian ini yaitu zakat, pendapatan, bidang usaha, dan asset usaha, maka model MRA terdiri dari empat persamaan struktural yang dapat dijabarkan sebagai berikut:

1. Pengaruh zakat terhadap kemiskinan dengan kinerja amil sebagai variabel pemoderasi.

2. Pengaruh pendapatan terhadap kemiskinan dengan kinerja amil sebagai variabel pemoderasi.

3. Pengaruh bidang usaha terhadap kemiskinan dengan kinerja amil sebagai variabel pemoderasi.

4. Pengaruh asset usaha terhadap kemiskinan dengan kinerja amil sebagai variabel pemoderasi. 


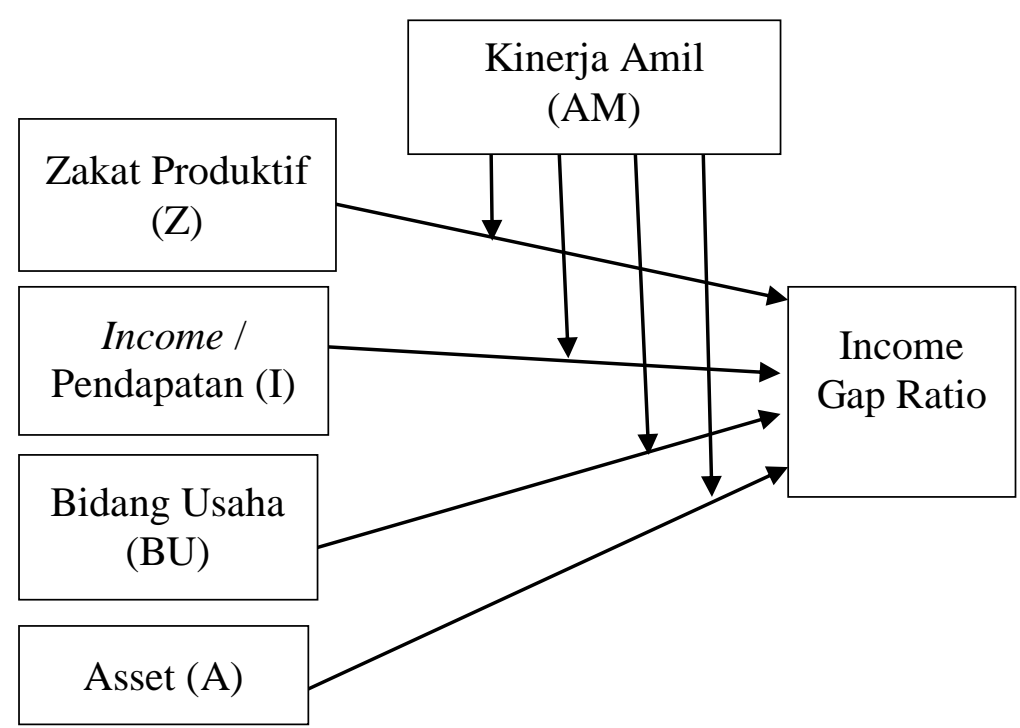

Gambar 2. Kerangka Model Penelitian

\section{METODE PENELITIAN}

Objek penelitian ini adalah masyarakat yang menerima zakat dalam bentuk produktif dari lembaga zakat Baitul Mal Kota Banda Aceh. Masyarakat yang menerima zakat disebut dengan mustahik, yaitu masyarakat miskin yang berhak menerima zakat dalam bentuk produktif dalam bentuk modal usaha mikro. Penelitian ini dilaksanakan di Kota Banda Aceh, dengan fokus penelitian pada kemiskinan perkotaan. Artinya indeks ukuran kemiskinan mengacu pada garis kemiskinan Kota Banda Aceh pada tahun 2017.

\section{Sampel}

Sampel dalam pelitian ini adalah mustahik yang menerima zakat dalam bentuk produktif yang bersumber dari Baitul Mal Kota Banda Aceh. Metode sampling yang digunakan dalam penelitian ini adalah nonprobability sampling. Metode ini dipilih karena tidak semua mustahik zakat menerima zakat dalam bentuk produktif. Berdasarkan ketentuan tersebut jumlah mustahik penerima zakat produktif Kota Banda Aceh yang ditetapkan adalah sebanyak 100 mustahik.

\section{Operasional Variabel}

Adapun yang menjadi operasional variabel dalam penelitian ini, terdiri atas variabel independen yaitu zakat produktif, pendapatan, bidang usaha, dan aset. Kemudian variabel dependent yaitu Income gap ratio. Selain variabel dependent dan independent, penelitian ini dielaborasi dengan variabel pemoderasi (moderating variabel) kinerja amil. Penjelasan rinci mengenai operasional variabel dapat dilihat dalam matriks pada Tabel 1 .

\section{Metode Analisis Data}

Secara umum, model regresi yang terdapat dalam penelitian ini dapat rumuskan dalam persamaan sebagai berikut:

$$
\begin{aligned}
\text { IncGap }= & a+b_{1} Z+b_{2} A m+b_{3} I+b_{4} B U+ \\
& b_{5} A+e
\end{aligned}
$$

dimana IncGap adalah Income Gap Ratio mustahik zakat; $\alpha$ adalah konstanta, $b_{1}$ sampai $b_{5}$ adalah koefisien regresi; $Z$ adalah jumlah zakat produktif; $A m$ adalah kinerja amil; $I$ adalah income; $B U$ adalah bidang usaha; $A$ adalah asset; dan $e$ adalah error term atau tingkat kesalahan penduga dalam penelitian.

Model regresi yang digunakan untuk menguji pengaruh variabel pemoderasi adalah uji interaksi dengan nilai Z-score pada masing-masing variabel. Metode analisis yang digunakan adalah moderated regression analysis (MRA). 
Tabel 1. Definisi Operasional Variabel

\begin{tabular}{|c|c|c|}
\hline Variabel & Definisi & Indikator \\
\hline Kemiskinan & $\begin{array}{l}\text { Selisih antara garis kemiskinan } \\
\text { dengan pendapatan mustahik } \\
\text { setelah zakat Produktif }\end{array}$ & $\begin{array}{l}\text { Perbandingan antara pendapatan } \\
\text { mustahik setelah zakat produktif } \\
\text { dengan garis kemiskinan Kota } \\
\text { Banda Aceh sebesar Rp. } 523.444,-\end{array}$ \\
\hline Kinerja Amil & $\begin{array}{l}\text { Kriteria kegiatan amil dalam } \\
\text { proses verifikasi, distribusi, dan } \\
\text { pemberdayaan zakat produktif }\end{array}$ & $\begin{array}{l}\text { 1. Verifikasi Sasaran mustahik } \\
\text { 2. Distribusi penyaluran } \\
\text { 3. Motivasi usaha } \\
\text { 4. Monitoring dan evaluasi }\end{array}$ \\
\hline Zakat Produktif & $\begin{array}{l}\text { Zakat yang diberikan kepada } \\
\text { mustahik untu kegiatan usaha } \\
\text { kecil/menengah }\end{array}$ & Nilai Zakat Produktif \\
\hline Pendapatan & $\begin{array}{l}\text { Kriteria penggunaan dana zakat } \\
\text { produktif dalam meningkatkan } \\
\text { pendapatan usaha }\end{array}$ & $\begin{array}{l}\text { 1. Penjualan } \\
\text { 2. Tambahan modal kerja } \\
\text { 3. Keuntungan }\end{array}$ \\
\hline Bidang Usaha & $\begin{array}{l}\text { Pengelompokan mustahik } \\
\text { berdasarkan klasifikasi usaha }\end{array}$ & $\begin{array}{l}\text { 1. Pertanian } \\
\text { 2. Peternakan } \\
\text { 3. Perikanan } \\
\text { 4. Perkebunan } \\
\text { 5. Perdagangan } \\
\end{array}$ \\
\hline Asset & $\begin{array}{l}\text { Kriteria penggunaan zakat } \\
\text { produktif yang digunakan untuk } \\
\text { aset usaha mustahik }\end{array}$ & $\begin{array}{l}\text { 1. Seluruh dana zakat untuk aset } \\
\text { usaha } \\
\text { 2. Dana zakat disisihkan } \\
\text { sebagian untuk aset usaha } \\
\text { 3. Dana zakat lainnya. }\end{array}$ \\
\hline
\end{tabular}

Unit analisis MRA ini menggunakan variabel pemoderasi sebagai variabel yang memperkuat atau memperlemah hubungan langsung antara variabel independen dengan variabel dependen. Moderated Regression Analysis (MRA) merupakan model khusus regresi linear yang persamaan regresinya memiliki unsur interaksi antar variabel (Ghozali, 2014). Dalam penelitian ini penggunaan MRA adalah dimaksudkan untuk menguji adanya peran Amil zakat produktif sebagai moderator variabel antara keempat variabel independen terdiri dari zakat produktif, pendapatan mustahik, bidang usaha, dan asset usaha.

Berkaitan dengan penggunaan MRA sebagai alat analisis data, Solimun (2011) menyatakan moderasi dapat dikatagorikan dalam empat kelompok sebagai berikut:

1. Moderasi Murni (Pure Moderator); terjadi ketika variabel moderasi berinteraksi dengan predictor variable tanpa menjadi variabel prediktor. Tipe moderasi ini muncul jika pengaruh variabel moderasi secara parsial (sebelum interaksi) terhadap variabel dependen adalah tidak signifikan, tetapi pengaruh interaksi antara variabel moderasi dengan variabel independen terhadap variabel dependen signifikan.

2. Moderasi Semu (Quasi Moderator); terjadi jika pengaruh variabel moderasi sebelum adanya interaksi dengan variabel independen, terhadap variabel dependen signifikan, dan pengaruh variabel moderasi setelah adanya interaksi dengan variabel independen juga signifikan.

3. Moderasi Potensial (Homologizer Moderator); terjadi saat pengaruh variabel moderasi setelah adanya interaksi dengan variabel independen juga tidak signifikan.

4. Moderasi Prediksi (Predictor Moderator); terjadi ketika pengaruh variabel moderasi terhadap variabel dependen signifikan, tetapi pengaruh interaksi antara variabel 
moderasi dengan variabel independen terhadap variabel dependen adalah tidak signifikan.

Secara statistik, penerapan MRA untuk menguji keberadaan amil sebagai variabel pemoderasi di antara keempat variabel independen tersebut dengan income gap ratio dapat diformulasikan ke dalam 4 (empat) persamaan struktural sebagai berikut:

IncGap $=a+b_{1} Z+b_{2} A m+b_{3} Z * A m+e$

IncGap $=a+b_{4} I+b_{5} A m+b_{6} I^{*} A m+e$

IncGap $=a+b_{7} B U+b_{8} A m+b_{9} B U^{*} A m+e$

IncGap $=a+b_{10} A+b_{11} A m+b_{12} A * A m+e$

dimana $a$ adalah konstanta; IncGap adalah Income Gap Ratio; $b_{1}$ sampai $b_{12}$ adalah koefisien regresi; $A m$ adalah kinerja amil; $Z$ adalah zakat produktif; I adalah Income; $B U$ adalah bidang usaha; dan, $A$ adalah asset.

\section{HASIL ANALISIS}

Sebagaimana dijelaskan sebelumnya, guna menganalisis keberadaan kinerja amil sebagai moderating variable terhadap hubungan kausalitas antara zakat, pendapatan, bidang usaha, dan asset usaha dengan kemiskinan digunakan adalah moderated regression analysis (MRA). Penggunaan model statistik tersebut akan dapat mengungkapkan sejauh mana peran kinerja amil dalam memoderasi pengaruh masingmasing variabel independen terhadap reduksi kemiskinan (income gap ratio) di Kota Banda Aceh. Sesuai dengan kaedah MRA yang kemudian disesuaikan dengan jumlah variabel independen dalam penelitian ini yaitu zakat, pendapatan, bidang usaha, dan asset usaha, maka persamaan MRA terdiri dari empat persamaan struktural. Hasil pengujian dirangkum dalam Tabel 2.

Berdasarkan hasil pengolahan dengan menempatkan kinerja amil sebagai MRA variabel, maka keempat persamaan struktural dapat dituliskan sebagai berikut:

$$
\text { 1. IncGap = } \begin{aligned}
& -1,864-0,168 \mathrm{Z}+0,327 \mathrm{Am}- \\
& 0,156 \mathrm{Z} * \mathrm{Am}+e
\end{aligned}
$$

2. IncGap $=-1,066-0,172 I+0,323 \mathrm{Am}-$ $0,266 I * A m+e$

3. IncGap $=-2,876+0,199 B U+0,139 A m+$ $0,122 B U^{*} A m+e$

4. IncGap $=-1,462+0,036 A+0,327 A m-$ $0,319 A * A m+e$

Secara umum dapat dijelaskan bahwa kinerja amil sebagai moderating variable berpengaruh signifikan terhadap income gap ratio pada taraf keyakinan $f$-stat sebesar $99 \%$ ( $p$-value < 0,01). Namun adanya respon yang berbeda-beda berkaitan dengan hubungan kausalitas antar variabel-variabel. Hubungan kausalitas yang berbeda-beda ini tersebut menunjukkan bahwa kinerja amil ada yang memperkuat income gap ratio dan adapula yang memperlemah income gap ratio.

Pada persamaan pertama, zakat mampu mereduksi income gap ratio dengan taraf keyakinan sebesar $90 \%$. Selanjutnya pengaruh kinerja amil terhadap income gap ratio signifikan pada taraf keyakinan sebesar $99 \%$. Dengan melibatkan keberadaan kinerja amil sebagai variabel pemoderasi (Zakat*Am), pengaruh zakat terhadap income gap ratio signifikan pada tingkat keyakinan sebesar 90\%. Hal ini berarti bahwa kinerja amil menjadi moderating variabel dalam kaitannya dengan zakat terhadap income gap ratio tergolong pada moderasi semu (quasi moderator). Hal ini disebabkan karena pengaruh variabel kinerja amil sebelum dan sesuda adanya interaksi dengan variabel zakat sama-sama berpengaruh signifikan.

Jika dilihat dari tanda dan besaran pengaruh, maka interasi antara kinerja amil dan zakat mampu mereduksi kemiskinan, di mana apabila interaksi kinerja amil dan zakat mampu ditingkatkan 1\%, maka akan mampu mereduksi income gap ratio sebesar $0,156 \%$. Hasil ini menegaskan bahwa keeratan hubungan antara zakat produktif dengan kinerja amil dalam menyalurkan zakat produktif diperkirakan dapat menurunkan angka kemiskinan yang tercermin dari turunnya kesenjangan pendapatan antar mustahik. 
Tabel 2. Hasil Analisis Statistik

\begin{tabular}{llll}
\hline Variabel & Koefisien & t-hit & Sig \\
\hline MODEL 1 & & & \\
\hline Konstanta & $-1,864$ & $-5,011$ & 0,000 \\
Zakat (Z) & $-0,168$ & $-1,647$ & 0,103 \\
Kinerja Amil (Am) & 0,327 & 3,492 & .001 \\
Zakat*Kinerja Amil (Z*AM) & $-0,156$ & $-1,537$ & 0,128 \\
\hline
\end{tabular}

Koefisien Determinasi $\left(\mathrm{R}^{2}\right)=0,183$

F-Stat $=7,072$

Sig F-Stat $=0,000$

\begin{tabular}{llll}
\hline MODEL 2 & & & \\
\hline Konstanta & $-1,066$ & $-2,382$ & 0,019 \\
Kinerja Amil (Am) & 0,323 & 3,598 & 0,001 \\
Income (I) & $-0,172$ & $-1,830$ & 0,070 \\
Income*Kinerja Amil (I*AM) & $-0,266$ & $-2,825$ & 0,006 \\
\hline
\end{tabular}

Koefisien Determinasi $\left(\mathrm{R}^{2}\right)=0,237$

F-Stat $=9,857$

Sig F-stat $=0,000$

\begin{tabular}{llll}
\hline MODEL 3 & & & \\
\hline Konstanta & $-2,876$ & $-6,260$ & 0,000 \\
Bidang Usaha (BU) & 0,199 & 1,901 & 0,06 \\
Kinerja Amil (Am) & 0,319 & 3,163 & 0,002 \\
Bidang Usaha*Kinerja Amil (BU*Am) & 0,122 & 1,164 & 0,247 \\
\hline
\end{tabular}

Koefisien Determinasi $\left(\mathrm{R}^{2}\right)=0,181$

F-Stat $=6,982$

Sig F-stat $=0,000$

\section{MODEL 4}

\begin{tabular}{llll}
\hline Konstanta & $-1,462$ & $-3,907$ & 0,000 \\
Kinerja Amil(Am) & 0,327 & 3,564 & 0,001 \\
Asset (A) & 0,036 & 0,335 & 0,739 \\
Asset*Kinerja Amil (A*Am) & $-0,319$ & $-2,978$ & 0,004 \\
\hline
\end{tabular}

Koefisien Determinasi $\left(\mathrm{R}^{2}\right)=0,201$

F-Stat $=7,949$

Sig F-stat $=0,000$

Sumber: Data Primer diolah, 2018

Selanjutnya pada persamaan yang kedua dengan menempatkan kinerja amil dalam kaitannya pada hubungan antara pendapatan dengan income gap ratio menghasilkan nilai koefisien determinasi yang paling besar, yaitu $23,87 \%$. Keseluruhan variabel juga pengaruh signifikan dengan tingkat kepercayaan yang tinggi sebsar 99\%.Adapun pada persamaan yang kedua, efek moderasi yang ditimbulkan adalah moderasi semu (quasi moderator).
Jika dilihat dari tanda dan besaran koefisien, maka kemiskinan dapat direduksi apabila pendapatan dan interaksi antara kinerja amil dengan pendapatan mampu ditingkatkan.Sementara kinerja amil saja tidak langsung direspon dengan adanya penurunanpenurunan income gap ratio. Maknanya adalah kemampuan dari mustahik dalam meningkatkan pendapatan yang disertai penguatan kinerja amil dalam melalukan 
pembedayaan dapat mereduksi kemiskinan di Kota Banda Aceh. Hubungan kausalitas ini dapat dimaknai apabila pendapatan usaha dan kinerja amil meningkat sebesar $1 \%$ maka kemiskinan dapat direduksi sebesar 0,266.

Persamaan ketiga mencoba melakukan elaborasi interaksi antara distribusi bidang usaha dengan kinerja amil terhadap kemiskinan. Perolehan hasil terlihat tidak signifikan dimana interaksi kedua variabel tersebut menghasilkan p-value sebesar 0,247. Efek moderasi ini tergolong kedalam moderasi prediksi (predictor moderator), di mana interaksi variabel amil zakat dengan distribusi bidang usaha justru tidak signifikan.

Adapun justifikasi hasil yang bisa dijelaskan dalam persamaan yang ketiga ini adalah bahwa kinerja amil di dalam mengelompokkan bantuan zakat produktif berdasarkan bidang usaha tidak berpengaruh pada penurunan angka kemiskinan. Hal ini diperkirakan terjadi karena secara umum kelompok mustahik penerima zakat produktif sebagian besar berprofesi sebagai pedagang atau pengusaha kecil sehingga distribusi bantuan berdasarkan bidang usaha dianggap tidak relevan dalam kaitannya mereduksi kemiskinan.

Persamaan keempat melakukan upaya menempatkan variabel asset dan kinerja amil sebagai moderating variabel berkaitan dengan pengaruh terhadap kemiskinan. Hasilnya adalah interaksi dari kedua variabel ini berpengaruh secara signifikan terhadap kemiskinan dengan taraf kepercayaan sebesar 99\%. Efek moderasi yang ditimbulkan dalam persamaan ini adalah moderasi murni (pure moderation). Dengan kata lain, dapat dijelaskan bahwa model persamaan yang keempat ini menempatkan kinerja amil sebagai moderating variabel yang penting dalam hubungan kausalitas antara asset dengan kemiskinan.

Pengaruh interaksi antara asset usaha dengan kinerja amil bertanda negatif dan siginifikan, dimana variabel pemoderasi mampu mereduksi kemiskinan sebesar $0,319 \%$. Pengaruh ini memiliki nilai koefisien yang paling besar dalam mereduksi income gap ratio jika dibandingkan variabel independen lainnya, maka bisa diestimasikan bahwa kinerja amil zakat produktif dalam melakukan pembinaan pada asset usaha akan diiringi dengan turunnya income gap ratio.

\section{Pembahasan}

Menurut Rusli Rusli, dkk (2013) dalam artikelnya yang berjudul "Analisis Dampak Pemberian Modal Zakat Produktif Terhadap Pengentasan Kemiskinan di Kabupaten Aceh Utara", mengungkapkan bahwa pemberian modal zakat produktif dalam bentuk modal usaha memiliki dampak positif dan dapat menurunkan angka kemiskinan di Kabupaten Aceh Utara sebesar $0,02 \%$. Oleh karena itu, pemberian zakat produktif dalam bentuk modal usaha oleh Baitul Mal Kabupaten Aceh Utara dapat dilanjutkan dan ditingkatkan. Lebih lanjut lagi, hasil penelitian milik Basyah (2009) memberi penjelasan tentang mekanisme administrasi dan pengelolaan zakat di Aceh. Pengelolaan zakat di Aceh memiliki kekhususan dalam berbagai daerah lain di Indonesia. Perbedaan utama adalah Baitul Mal sebagai lembaga resmi yang bertanggungjawab sebagai lembaga pengelolaan zakat di Aceh. Mekanisme pengelolaan zakat di Baitul Mal Aceh dalam memberantas kemiskinan melalui program pemberdayaan ekonomi masyarakat menghasilkan manfaat dalam jangka panjang dan melepaskan kebergantungan ekonomi dari pihak lain. Justru Baitul Mal Aceh telah berperanan sangat penting dalam pembangunan ekonomi masyarakat miskin di Aceh.

Penyaluran zakat produktif menjadi salah satu sasaran dalam program Baitul Mal Kota Banda Aceh dalam rangka pemberdayaan ekonomi masyakarat dengan memberi bantuan modal usaha, baik berupa dana/uang, peralatan, mesin, dan barang modal lainnya. Amil sebagai salah satu komponen penting dalam penyaluran zakat produktif melaksanakan tiga tugas utama, yaitu proses verifikasi mustahik, penyaluran atau distrbusi, dan pemberdayaan. Berdasarkan ketiga indikator tersebut, variabel pemoderasi yang terbentuk terbagi dalam tiga tipe efek berikut:

1. Quasi Moderator.

Quasi moderator merupakan hasil estimasi MRA yang terbentuk dengan 
adanya pola hubungan yang signifikan sebelum dan setelah interaksi variabel pemoderasi dengan variabel independent. Efek quasi moderator terbentuk pada pengujian persamaan model 1 (interaksi zakat dengan kinerja amil) dan persamaan model 2 (interaksi pendapatan dengan kinerja amil). Implikasi yang dapat dijelaskan dari efek quasi moderator ini adalah kinerja amil merupakan satu kesatuan dengan jumlah zakat produktif dan pendapatan mustahik sebagai variabel independen.

Efek moderasi yang ditimbulkan dari persamaan ini menerangkan bahwa kinerja amil dalam hal verifikasi, penyaluran atau distribusi, dan pemberdayaan berhubungan dengan jumlah zakat dan pendapatan usaha dalam mereduksi kemiskinan. Efek moderasi dikatakan semu menggambarkan bahwa kinerja amil dapat menjadi variabel moderasi, sekaligus sebagai independent di sisi yang lain bersama-sama dengan jumlah zakat dan pendapatan dalam kaitannya dengan pengaruh terhadap kemiskinan.

\section{Predictor Moderator.}

Persamaan model yang ketiga (yaitu, interaksi bidang usaha dan kinerja amil) menghasilkan pengaruh bersifat yang tidak signifikan terhadap kemiskinan, namun tanpa adanya interaksi antara variabel bidang usaha dengan kinerja amil menghasilkan pengaruh yang signifikan. Implikasi dari hasil estimasi MRA bahwa kinerja amil dengan bidang usaha menemukan bahwa bidang usaha merupakan prediktor (variabel independen) yang mempengaruhi kemiskinan. Atau dengan kata lain bisa disimpulkan bahwa pengelompokkan bidang usaha tidak berinteraksi dengan kinerja amil dalam penurunan kemiskinan.

\section{Pure Moderator.}

Persamaan keempat menghasilkan sifat estimasi yang signifikan setelah menempatkan interaksi antara variabel kinerja amil dan asset usaha. Temuan dari hasil persamaan MRA ini memberikan justifikasi bahwa kinerja amil mampu memperkuat hubungan kausalitas asset usaha terhadap kemiskinan. Implikasi dari model persamaan yang keempat ini menyimpulkan bahwa kinerja amil dalam meningkatkan asset usaha mustahik mampu mereduksi atau menurunkan tingkat kemiskinan di Kota Banda Aceh.

\section{KESIMPULAN}

Hasil penelitian menyimpulkan bahwa kinerja amil menjadi bagian yang penting dalam mereduksi tingkat kemiskinan.efek moderasi yang terjadi terbagi dalam kelompok efek quasi moderator, predictor moderator, dan pure moderator. Kinerja amil memoderasi pengaruh zakat dan pendapatan terhadap kemiskinan di Kota Banda Aceh dengan efek quasi moderasi. Sementara interaksi antara kinerja amil dan pengelompokan bidang usaha menghasilkan efek predictor moderator atau tidak adanya pengaruh interaksi terhadap kemiskinan. Efek moderasi yang kuat dan pure moderator terjadi dalam interaksi antara asset usaha dengan kinerja amil. Oleh karena itu, hubungan yang kuat ini menyimpulkan bahwa kemiskinan dapat direduksi jika kinerja amil dapat selaras dengan pemberdayaan asset usaha mustahik di Kota Banda Aceh.

\section{DAFTAR PUSTAKA}

Badan Pusat Statistik. 2016. Jumlah dan Persentase Penduduk Miskin, Garis Kemiskinan, Indeks Kedalaman Kemiskinan (P1), dan Indeks Keparahan Kemiskinan (P2) Menurut Provinsi, September 2016. Aceh: BPS Provinsi Aceh.

Badan Pusat Statistik. 2016. Statistik Kota Banda Aceh 2016. Banda Aceh: BPS Kota Banda Aceh

Basyah, A.M. 2009. Pentadbiran Zakat di Baitul Mal Aceh: Kajian terhadap Agihan Zakat bagi Permodalan Masyarakat Miskin. Disertasi. Kuala Lumpur: Akademi Pengajian Islam. Kuala Lumpur Universiti Malaya.

Bendadeh, S. 2016. Zakat Produktif: Transformasi Mustahik Menjadi Muzakki. Opini Baitul Mal Aceh. 
Ghozali, I. 2014. Structural Equation Modeling Metode Alternatif dengan Partial Least Square PLS. Edisi 4. Semarang: Badan Penerbit UNDIP.

Hafidhhuddin, D. 2002. Zakat dalam

Perekonomian Modern. Jakarta: Gema Insani.

Haughton, J. dan Khandker, S.R. 2009. Handbook on Poverty and Inequality. Washington, DC: The World Bank.

Huda, K. 2012. Fiqh Pengelolaan Zakat Produktif sebagai Upaya Pengembangan Sumber Daya Mustahik (Studi Kasus di Badan Pelaksana Urusan Zakat Muhammadiyah (BAPELURZAM) Pimpinan Cabang Muhammadiyah Weleri Kendal. Tesis. Semarang: Program Pascasarjana IAIN Walisongo.

Iqbal. 2011. Peranan dan Kuasa Lembaga Amil dalam Pengurusan Pentadbiran Zakat di Baitul Mal Aceh. Kuala Lumpur: ADIC.

Johari, F., dkk. 2015. The Role of Zakat in Reducing Poverty and Income Inequality among New Convert (Muallaf) in Selangor, Malaysia. Online Journal Research Islamic Studies. Vol. 1, No. 3, hal. 43-56.

McGee, T.G. 1971. The Urbanization Process in the Third World. London: G. Bells and Sons Ltd.
Muhammad. 2009. Lembaga Ekonomi Mikro Syari'ah: Pergulatan Melawan Kemiskinan dan Penetrasi Ekonomi Global. Yogyakarta: Graha Ilmu.

Nawawi, I. 2010. Zakat dalam Prespektif Fiqh, Sosial dan Ekonomi, Surabaya: CV. Putra Media Nusantara.

Qadir, A. 2001. Zakat (Dalam Dimensi Mahdah dan Sosial). Edisi Kesatu, Cetakan Kedua. Jakarta: PT. Raja Grafindo Persada.

Ridwan, M. 2005. Manajemen Baitul Maal Wa Tamwil (BMT). Cetakan Kedua. Yogyakarta: UII Press.

Rusli, dkk. 2013. Analisis Dampak Pemberian Modal Zakat Produktif terhadap Pengentasan Kemiskinan di Kabupaten Aceh Utara. Jurnal Universitas Syiah Kuala. Vol. 1, Februari.

Shalimow. 2004. Pemberdayaan Sektor Informal Masyarakat melalui P2KP. http://shalimow.com/pemberdayaan/pe mberdayaan-sektorinformalmasyarakatmelalui-p2kp-sekedar-abstraksi.html. Diakses pada tanggal 7 Juni 2017.

Solimun. 2011. Analisis Variabel Moderasi dan Mediasi. Malang: Fakultas Matematika dan Ilmu Pengetahuan Universitas Brawijaya.

Sugiyono. 2002. Metode Penelitian Bisnis. Bandung: Alfabeta. 